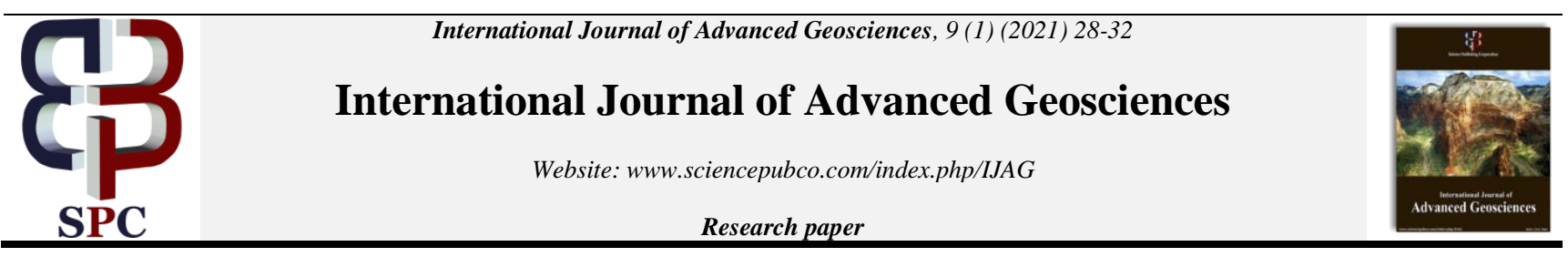

\title{
Foraminifera biostratigraphy and paleoenvironmental studies of well-x, eastern Niger delta
}

\author{
Samuel Ibukunoluwa Adeola ${ }^{1}$, John Adewole Adeola ${ }^{1}$, Victoria Abiola Dairo ${ }^{1}$ \\ ${ }^{1}$ Dept. of Physical and Earth Sciences, Crawford University, Faith-City, Igbesa. Nigeria \\ *Corresponding author E-mail: biola02ng@yahoo.com
}

\begin{abstract}
Ditch cutting samples from Well-X drilled in the Eastern part of the Niger delta were subjected to biostratigraphy and paleoenvironmental studies using micropaleontological analysis to identify the foraminifera present in the sections penetrated by the well.

A total of 50 (fifty) foraminifera species made up of benthonic and planktic spp were recovered from the sections. The marker species identified are Globorotalia acostaensis, Globorotalia mernadii cultrate, Neogloboquadrina dutertrei, Globorotalia plesiotumida, Globorotalia obesa, Globorotalia nepenthes, Sphaeroidinella subdehiscens, Neogloboquadrina dutertrei, Globigerinoides sudquadratus.

The four (4) biozones identified are N16 (Late Miocene 9.5Ma - 10.9Ma), N15-N14, N13-N12 and N12-N11 (Middle Miocene with corresponding ages $10.9 \mathrm{Ma}-11.8 \mathrm{Ma}, 11.8 \mathrm{Ma}-12.2 \mathrm{Ma}$ and $12.2 \mathrm{Ma}$ respectively).

Using the encountered benthonic foraminiferal species, the paleoecology was determined; and it was revealed that the paleoenvironment of the section ranges from Inner Neritic to Outer Neritic Environment. Also, the lithological analysis revealed an intercalation of Shale, Mudstone and Sand which indicates various paleoecological episodes that led to their deposition.

The age of the well was inferred from the bioevents of the marker species to be Middle Miocene to Late Miocene with the sparse occurrence of the Calcareous Benthic and the Plankonic species suggesting a shallow marine environment.
\end{abstract}

Keywords: Biozones; Marker Species; Foraminiferal; Environment and Paleoecology.

\section{Introduction}

Biostratigraphy amongst other applications is crucial in hydrocarbon exploration and exploitation in the Niger Delta. Though different microfossils amongst which are spores, pollen and foraminifera test linings have been employed to reconstruct the environment of deposition of studied sections and in age dating of rocks, the use of foraminifera cannot be overemphasized. This is because their remains are found in variable ecology. Thus, causing formations to have different depositional settings which imply different reservoir qualities in terms of architecture, connectivity, heterogeneity and porosity-permeability characteristics (Simmons et al., 1999).

This study involves an approach to foraminifera study in interpreting biostratigraphy, age dating of formations and their corresponding environment of deposition as penetrated by a deep-water discovery well (Well-X - 1200ft deep) located within the offshore in Niger Delta Basin.

\section{Geologic setting of the area}

The Niger Delta is found at the intersect of the Benue trough and the South Atlantic Ocean where a triple junction developed during the separation of the continents of South America and Africa in the late Jurassic (Whiteman, 1982).

The Niger delta has been fed by the Niger, Benue and Cross rivers, which between them drain more than $10^{6} \mathrm{~km}^{2}$ of continental lowland savannah. It is a large wave-dominated delta whose apex to coast sections' sub- aerial portion stretches more than $300 \mathrm{~km}$, covering an area of $75,000 \mathrm{~km}^{2}$.

The Delta sediments show an upward transition from marine pro-delta shales (Akata Formation) through a paralic interval (Agbada Formation) to a continental sequence (Benin Formation) as shown in Figure 1. These three sedimentary environments extend across the whole delta and range in age from Early Tertiary to Recent.

The type section of the Akata Formation was defined in Akata-1 Well, $80 \mathrm{~km}$ east of Port Harcourt (Short and Stauble, 1967). A total depth of 11,121 feet $(3,680 \mathrm{~m})$ was reached in the Akata-1 well without encountering the base of this formation. The top of the formation is defined by the deepest occurrence of deltaic sandstone beds (7,180 feet in Akata well). The formation is estimated to be 21,000 feet thick in the central part of the clastic wedge and comprises of lithologies made up of dark gray shales and silts, with rare streaks of sand of probable turbidite flow origin (Doust and Omatsola, 1989). The marine planktonic foraminifera present in them makes up to 50\% of the microfauna assemblage and suggest shallow marine shelf deposition. 


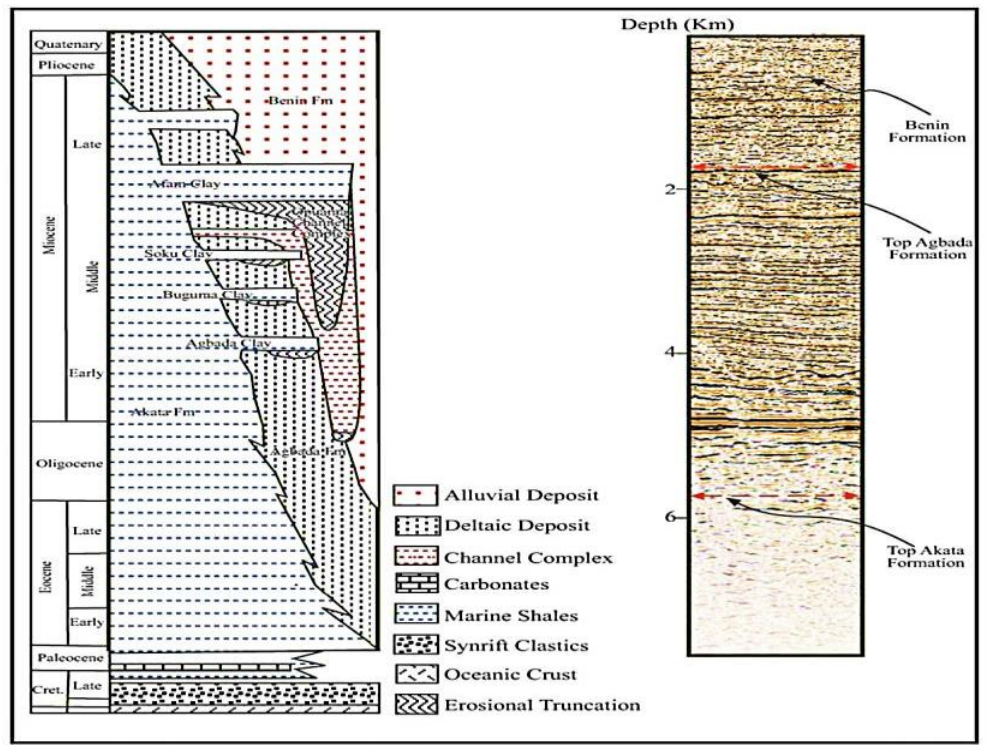

Fig. 1: Schematic Diagram of Niger Delta Regional Stratigraphy and Variable Density Seismic Display of the Main Stratigraphic Unit with Corresponding Reflection (Modified from Lawrence et al., 2002).

\section{Materials and methods}

40 (Forty) ditch cutting samples from Well-X were made available and the samples were collected at 30ft intervals from $753.3 \mathrm{~m}$ ( $2430 \mathrm{ft})$ to $1125.3 \mathrm{~m}$ (3630ft) These samples were subjected to micro paleontological analysis (foraminifera sample processing) and lithological analysis (lithological washing).

$5 \mathrm{~g}$ of each sample was poured into a pan beaker. The pan beakers were also labeled serially to majorly avoid contamination. Hydrogen Peroxide was added into the individual samples and there was an immediate effervescence reaction which typifies the presence of carbon in the samples. Detergent was added and left to stand overnight (i.e. for a period of at least 12 hours).Immediately this was done the washing and wet sieving was proceeded into.

The processed samples were washed and sieved in a $63 \mu \mathrm{m}$ sieve with a gentle jet of water from the laboratory tap until all the muds were removed. The clean residue was dried and packaged in well labeled bags ready for picking.

A binocular microscope, moistened picking brush $(000 \mathrm{~m})$, slides, cover slips, graded picking tray, and some water were employed during the picking. The dried samples were then scattered on the black graded picking tray, placed on the stage under a well illuminated binocular microscope, with the tray gently moved while microfossil specimens in it were picked and deposited into a labeled slide for storage and subsequent identification.

Foraminifera picked were identified using the journals and other manuals, monographs and publications dealing with the description of foraminifera from the general area under investigation.

The lithological analysis entails studying $20 \mathrm{~g}$ each of the samples under the microscope for their mineralogy, grain size, percentage of sand and shale, presence or absence of glauconite and carbonaceous materials. This information helps in environmental description.

\section{Results and interpretation}

Important foraminifera bioevents considered includes; First Downhole Occurrence (FDO) of chronostratigraphically significant plankton/benthic foraminifera species, Last Downhole Occurrence (LDO) of plankton/benthic foraminifera marker species and Foraminifera abundance and diversity peaks dated with foraminifera marker species whose stratigraphic ranges are well established in the Niger delta and worldwide.

\subsection{Abundance and diversity of species}

Recovered foraminifera assemblages were generally poor to moderate. Arenaceous foraminifera species dominated the assemblage while planktons and calcareous benthos were generally sparsely distributed.

Foraminifera distribution, abundance and diversity chart of the recovered forms together with the foraminifera zones are represented below in Figures 2 and 3. Index forms among the recovered foraminifera assemblages have been used in dating and zoning the intervals. 

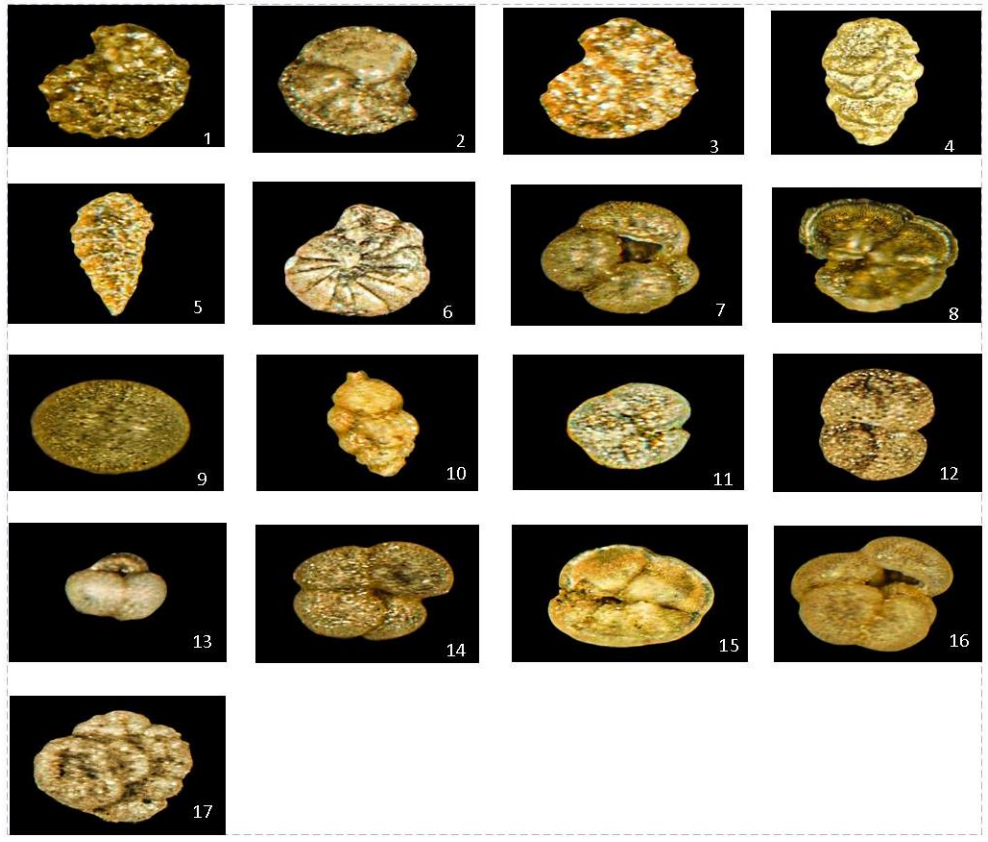

Fig. 2: Foraminifera Marker Species Identified in X-Well (Scale - 9um)

1.) Cyclammina of Minima Leroy 2.) Globorotalia Margariate Bolli and Bermudez 3.)Ammobaculites Strathearnensis Cushman and Leroy 4.) Valvulina Flexilis Cushman and Renz 5.) Textularia Parvula Cushman 6.) Cyclammina Cancellata Brady 7) Globoquadrina Dehiscens Chapman, Parr \& Collins 8.) Globorotalia Plesiotumida Banner And Blow 9.) Orbulina Universa d'Orbigny 10.) Uvigerina Proboscidea Schwager 11.) Globorotalia Acostaensis Blow 12.) Globigerinoides Immaturus Leroy 13.) Globigerina Nepenthes Todd 14.)Globorotalia Pseudopima Bolli and Blow 15.) Globorotalia Menardii Bolli and Bermudez 16.) Neogloboquadrina Dutertrei d'Orbiginy 17.)Haplophragmoides Narivaensis Bronnimann

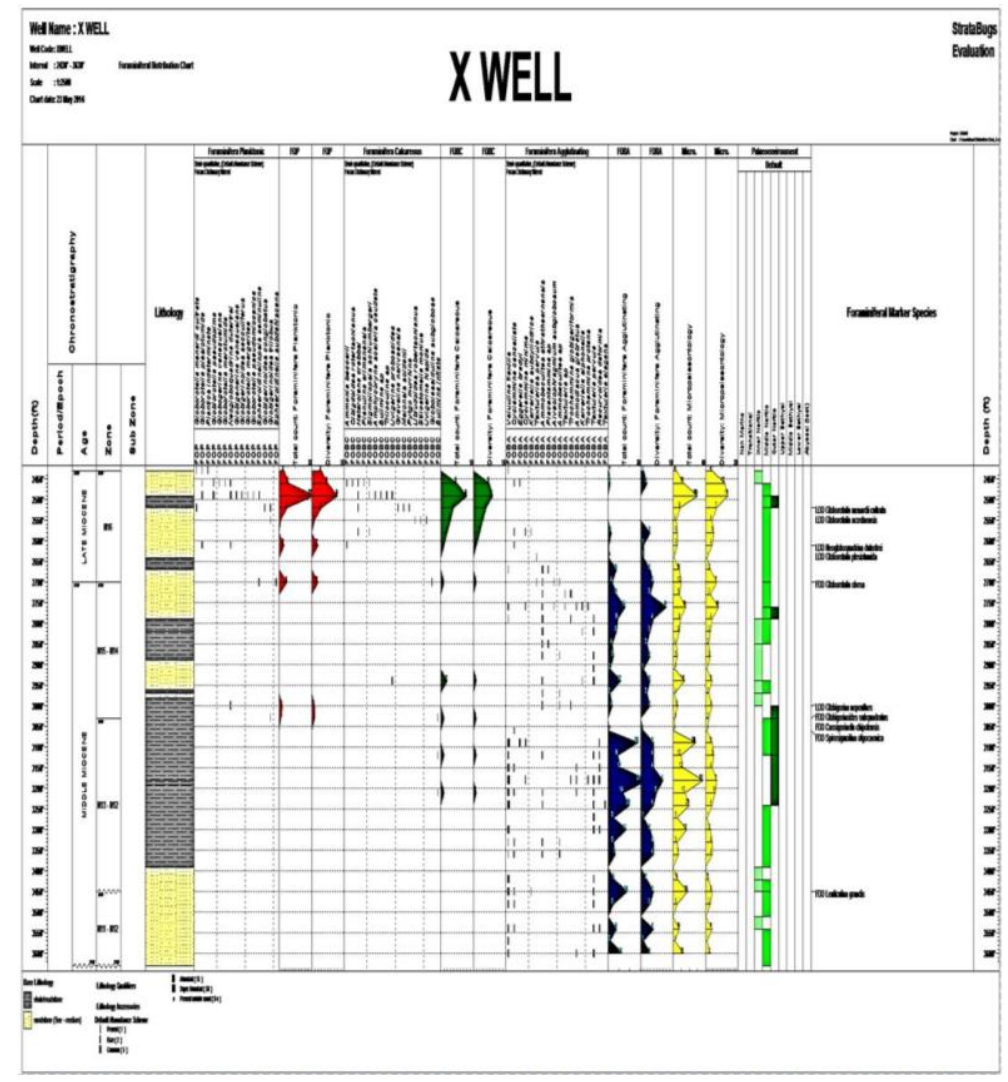

Fig. 3: Typical Foraminifera Distribution Chart of X-Well.

Interval: $753.3 \mathrm{~m}(2430 \mathrm{ft})-837 \mathrm{~m}(2700 \mathrm{ft})$

Planktic Zone: N16

Estimated Numerical age: Late Miocene (9.5Ma -10.9Ma)

Remarks: A marked increase in foraminifera abundance, diversity characterized this interval. This abundance/diversity of species within this interval is thought to be within a condensed section topped with 9.50Ma marine flooding event. Last Downhole Occurrence (LDO) of Globorotalia acostaensis (10.9Ma) at $2520 \mathrm{ft}$ confirms this event. The zonal interval is dominated by planktic species and also by sparse calcareous benthics and arenaceous species.

Interval: $939.3 \mathrm{~m}$ (3030ft)- $1069.5 \mathrm{~m}(3450 \mathrm{ft})$

Planktic zone: N13-N12

Estimated numerical age: $11.8 \mathrm{Ma}-12.2 \mathrm{Ma}$ 
Remarks: Rare occurrences of planktics and calcareous benthic species characterized this interval. Arenaceous species dominated the foraminiferal assemblage consisting of Eggerella scabra, Ammobaculites agglutinans, Haplophragmoides narivaensis, Haplophragmoides compressa, valvulina flexilis, Alveolophragmium crassum and Cyclammina cancellata.

\subsection{Foraminifera biozonation}

The foraminifera zonation of X well was guided by the works of Blow $(1969,1979)$, and Berggren (1995) while the numerical ages (Ma) were based on the works of Vail and Wornart (1991) and Berggren (1995). Condensed sections / Maximum Flooding surfaces were correlated to the Global cycle chart of Haq et al (1988).

Interval: $753.3 \mathrm{~m}(2430 \mathrm{ft})-837 \mathrm{~m}(2700 \mathrm{ft})$

Planktic Zone: Globorotalia acostaensis zone - N16

Estimated Numerical age: Late Miocene - (Turtonian) $9.5 \mathrm{Ma}-10.9 \mathrm{Ma}$

Definition: Age assigned to this interval is based on

- $\quad$ Last Downhole Occurrence (LDO) of Globorotalia acostaensis at $781.2 \mathrm{~m}(2520 \mathrm{ft})$

- Last Downhole Occurrence (LDO) of Globorotalia mernadii cultrate at $781.2 \mathrm{~m}(2520 \mathrm{ft})$.

- $\quad$ Last Downhole Occurrence (LDO) of Neogloboquadrina dutertrei at $812.2 \mathrm{~m}(2620 \mathrm{ft})$.

- $\quad$ Last Downhole Occurrence (LDO) of Globorotalia plesiotumida at $815.3 \mathrm{~m}(2630 \mathrm{ft})$

- First Downhole Occurrence (FDO) of Globorotalia obesa at $837 \mathrm{~m}(2700 \mathrm{ft})$

Remarks: The co-occurrence of Globorotalia dehiscens, Globorotalia pseudopima, Globorotalia merotumida, Globorotalia nepenthes, Sphaeroidinella subdehiscens, Neogloboquadrina dutertrei confirmed the Late Miocene age.

Interval: $837 \mathrm{~m}(2700 \mathrm{ft})-939.3 \mathrm{~m}(3030 \mathrm{ft})$

Planktic Zone: N15-N14

Estimated Numerical Age: Middle Miocene (Early Turtonian - Late Serravalian) 10.9Ma-11.8Ma

Definition: The interval's age is based on:

- $\quad$ Last Downhole Occurrence (LDO) of Globorotalia nepenthes at $936.2 \mathrm{~m}$ (3020ft)

- $\quad$ First Downhole Occurrence (FDO) of Globigerinoides sudquadratus at $939.3 \mathrm{~m} \mathrm{(3030 \textrm {ft } )}$

Remarks: This zonal interval is devoid of chronostatigraphically significant bioevents. Age and zonal inferences are based on the relative stratigraphic position of this interval below the dated overlying sediments.

Interval: $939.3 \mathrm{~m}(3030 \mathrm{ft})-1069.5 \mathrm{~m}(3450 \mathrm{ft})$

Planktic zone: N13-N12

Estimated numerical age: Middle Miocene (Serravalian) 11.8Ma-12.2Ma

Definition: The above age classification is based on;

- The First Downhole Occurrence (FDO) of Globigerinoides subquadratus at 936.2m (3020ft.)

- $\quad$ The First Downhole Occurrence (FDO) of Cassigerinella chilopllensis at 939.3m (3030ft)

- The First Downhole Occurrence (FDO) of Spirosigmoilina oligocaenica (depressed) at $951.7 \mathrm{~m}$ (3070ft)

Remarks: The observed moderate abundance and diversity of foraminferal species between (3010ft) $933.1 \mathrm{~m}-945.5 \mathrm{~m}$ (3050ft) could be associated with marine flooding events and are positively dated as 11.5Ma Maximum Flooding surfaces (MFS) on the basis of the Last Downhole Occurrence of Globigerina nepenthes (11.8)Ma at $936.2 \mathrm{~m}(3020 \mathrm{ft})$.

Interval: (1069.5m) 3450ft-(1125.3m) 3630ft

Planktic zone: N12-N11

Estimated numerical age: Middle Miocene (Serravalian) 12.2Ma

Definition: The age assigned to this level is based on;

- $\quad$ The First Downhole Occurrence (FDO) of Lenticulina grandis at $1069.5 \mathrm{~m}$ (3450ft).

Remarks: The interval is characterized by sparse planktic foraminifera. Benthic foraminiferal species within the interval are long ranging and this interval is dominated by arenaceous forms.

General statement: There is Maximum Flooding Surfaces (MFS) at $783.68 \mathrm{~m}$ (2528ft) and also at $942.4 \mathrm{~m}(3040 \mathrm{ft})$.

The results of the analysis indicates that the studied area was deposited during the Late Miocene to Middle Miocene epoch, of estimated numerical age of 9.5 Ma to 10.9Ma and straddling the Globorotalia plesiotumida of Berggren (1995) and Globorotalia acostaensis (N16) zones of Blow (1979).

\subsection{Paleoenviromental Interpretations}

Integration of sedimentological, wireline log characters and micropaleontological characteristics have enhanced the deductions of varying depositional environments over the analyzed interval $(753.3 \mathrm{~m}) 2430 \mathrm{ft}-(1125.3 \mathrm{~m}) 3630 \mathrm{ft}$ of X-Well.

Micropaleontologically, paleoenvironmental deductions were based primarily on benthic foraminiferal assemblage, abundance and diversity of species. Presence or absence of planktic foraminiferal also helped in deciphering open ocean environments.

Lithologic characteristics including well log signatures, sand/shale ratios, and textural attributes of sands and accessory mineral compositions of samples were used to define the depositional environments recorded over the studied section (753.3m) $2430 \mathrm{ft}-(1125.3 \mathrm{~m}) 3630 \mathrm{ft}$ of X-Well.

The results of the palynomaceral analysis of the $\mathrm{X}$-Well were integrated with microforaminiferal and sedimentological data to infer the environments of deposition of the well with emphasis laid on foraminifera.

Interval: (753.3m) 2430ft- $(844.75 \mathrm{~m}) 2725 \mathrm{ft}$

(Pro-delta shales/Mudstones with occasional regressive sand deposits): The lower half of this unit (796.7m) $2570 \mathrm{ft}-(844.75 \mathrm{~m}) 2725 \mathrm{ft}$ was dominated by arenaceous species including Valvulina flexilis, Haplophragmoides compressa, Haplophragmoides narivaensis, Alveolophragmium crassum, Saccammina complanata and Cyclammina cancellata. This suggests deposition within Middle to Outer Neritic. There is a gradual increase in the diversity and population of planktic and calcareous benthos species within this unit.

Beyond (796.7m) 2570ft, there was a sharp decrease in arenaceous species and a corresponding increase in calcareous benthos and planktis species. Foraminiferal assemblages within this interval includes; Melonis soldanii, Sigmoilopsis schlumbergeri, Uvigerina proboscidea, Bulimina inflate, Heterolepa crebssi and common planktons species dominated by the genera Globigerinoides and Globorotalia. This foraminiferal association is indicative of sediment deposition in a predominantly outer to upper bathyal. The arenaceous species which 
dominated the underlying unit were becoming insignificant constituents of the unit. Also observed is a corresponding increase in paleowater depth from the base to the top of this unit.

Interval: (844.75m) $2725 \mathrm{ft}-(1109.2 \mathrm{~m}) 3578 \mathrm{ft}$

(Shelf mudstone interbedded with off shore sands): This is a massive sequence of grey to dark, platy, moderately soft shale/mudstones interbedded with fine to medium occasionally coarse sub angular to sub rounded and moderately well sorted sands.

There is also a gradual increase in abundance and diversity of arenaceous benthis species and a corresponding decline in the calcareous benthic and planktis characterized this unit. The observed bloom in the arenaceous foraminiferal species and became important constituents of the microfauna within this unit.

The foraminiferal associations include Valvulina flexilis, Haplophragmoides narivaensis, Haplophragmoides, Karriela siphonella, Cyclammina cancellata, and Cyclammina minima. This foraminiferal associations is suggestive of sediment deposition in outer to bathyal environment probably below CCD where calcareous foraminifera's have been largely dissolved.

Interval: (1109.2m) 3578ft- (1125.3m) 3630ft.

(Low stand Prograding complex): This is a sequence of regressive sands/sandstones with occasional silts/siltstones and shallow marine shale's. This depositional unit is characterized by foraminiferal assemblage that typified middle to outer Neritic environment. The foraminifera constituents recorded within this unit consist of both arenaceous and calcareous benthis species. This include Haplophragmoides compressa, Haplophragmoides narivaensis, Valvulina flexilis, Eggerella bradyi, Saccammina complanata, Alveolophragmium crassum, Hopkinsinna bunoniensis, Heterolepa pseudogeriana, Cibigdoides robertsonianus, Uvigeriana subperegrina and rare planktic species.

\section{Conclusion}

The ditch cutting samples provided from Well X which was drilled in the Eastern part of Niger Delta covering an interval of ( $372 \mathrm{~m})$ $1200 \mathrm{ft}$ i.e. from $(753.3 \mathrm{~m}) 2430 \mathrm{ft}$ to $(1125.3 \mathrm{~m}) 3630 \mathrm{ft}$ were employed for this biostratigraphic study.

The intense micropaleontological analysis carried out to recover the fossils yielded a total of 50 (fifty) foraminifera species made up of benthonic and planktic spp. The marker species identified are Globorotalia acostaensis, Globorotalia mernadii cultrate, Neogloboquadrina dutertrei, Globorotalia plesiotumida, Globorotalia obesa, Globorotalia nepenthes, Sphaeroidinella subdehiscens, Neogloboquadrina dutertrei, Globigerinoides sudquadratus.

Using the encountered benthonic foraminiferal species, the paleo-ecology was determined; and it was revealed that the paleoenvironment of the section ranges from Inner Neritic to Outer Neritic Environment. Also, the lithological analysis revealed an intercalation of Shale, Mudstone and Sand which indicates various paleoecological episodes that led to their deposition.

The age of the well was inferred from the bioevents of the marker sppecies to be Middle Miocene to Late Miocene with the sparse occurrence of the Calcareous Benthis and the Planktic species suggesting a shallow marine environment.

\section{References}

[1] Berggren, W.A, Kent. D.V, Swisher C.C. \& Aubrey M., 1995. A revised Cenozoic Geochronology and Chronostratigraphy. SEPM Special Publication, 54: 129-212 https://doi.org/10.2110/pec.95.04.0129.

[2] Blow, W.H., 1969. Late Middle Eocene to Recent planktic foraminiferal biostratigraphy. In: bronnimann,P. and Renz, H.H. Eds., Proceedings of the 1st International Conference on Planktonic Microfossils, Geneva, 1: 199-422.

[3] Doust, H. \& Omatsola, E., 1989. Niger Delta. In Edwards, J. D. and Santogrossi, P. A. (Eds.): Divergent/passive margin basins, AAPG Memoir 48: 201-238.

[4] Haq, B.U., Hardenbol, J. \& Vail, P.R., 1987. Chronology of Flunctuating Sea Levels since the Triassic. Science, 235: 1156-1166. https://doi.org/10.1126/science.235.4793.1156.

[5] Lawrence SR, Munday S, Bray R (2002) Regional Geology and Geophysicsof Eastern Gulf of Guinea (Niger Delta to Rio Muni). Leading Edge, 21: 1112-1117. https://doi.org/10.1190/1.1523752.

[6] Short, K. C. \& Stauble, A. J. (1967) Outline of the geology of Niger Delta. American Association of Petroleum Geologists Bulletin, 51: 761-779. https://doi.org/10.1306/5D25C0CF-16C1-11D7-8645000102C1865D.

[7] Simmons, M.D.; M.D. Bidgood, P. Brenac, P.D., Crevello, J.J., Lambiase \& Morley, C.K.., 1999. Microfossil assemblages as proxies for precise palaeorenvironmental determination-an example from Miocene sediments of northwest Borneo, in R.W. Jones and M.D. Simmons, eds; Biostratigraphy in Production and Development Geology: Geologiocal Society Special Publication, no. 152, 219p. https://doi.org/10.1144/GSL.SP.1999.152.01.13.

[8] Whiteman, A.J., 1982. Nigeria: Its petroleum geology, resources and potentials. London: Graham and Trotman, 1: 176, 2: 238. https://doi.org/10.1007/978-94-009-7361-9_1.

[9] Vail, P.R. and Wornardt, W.W. (1991): An integrated approach to exploration and development in the 90s: Well log-seismic sequence stratigraphic analysis. Gulf Coast: Association of Geological Society transaction, 41: 430-650. 